\title{
Instructional Materials and English Reading Literacy of Pupils in Universal Primary Education Schools in Fort Portal Municipality in Uganda
}

\author{
${ }^{1}$ Elizabeth Rwamwenge, ${ }^{1}$ Dinensio Kiyundo Zikanga, ${ }^{2}$ Wilson Mugizi, \\ (Corresponding Author: wilsonmugizi@kiu.ac.ug) \\ ${ }^{1}$ Faculty of Education Kampala International University Western Campus \\ ${ }^{2}$ Directorate of Postgraduate Studies and Research Kampala International University Western Campus
}

\begin{abstract}
This study investigated whether instructional materials determined English reading literacy of pupils in UPE Schools in Fort Portal Municipality in Uganda. The objectives of the study were to assess whether audio-visual instructional materials, graphic instructional materials and realia instructional materials determine the variation in pupils reading literacy in primary schools. The study adopted the quantitative approach only using an experimental research design on a sample of 327 pupils. An English reading test with question items on audio-visual, graphic and realia instructional materials was administered on pupils. Data were analysed using Student's $\mathrm{t}-$ test. The results revealed that audio-visual, graphic and realia instructional materials contributed to the variation in pupils' English reading literacy in primary schools. Therefore, it was concluded that the use of audio-visual instructional materials, graphic instructional materials and realia instructional materials is imperative for pupils reading literacy in Primary Schools. It was thus recommended that the Ministry of Education, head teachers and proprietors of schools should help teachers in primary schools to emphasise the use of audio-visual instructional materials, graphic instructional materials and realia instructional materials in teaching English reading literacy to pupils in primary schools.
\end{abstract}

Key Word: Audio-Visual, English Reading Literacy, Graphic, Instructional Materials, Realia.

DOI: $10.7176 / \mathrm{JEP} / 11-6-03$

Publication date: February $29^{\text {th }} 2020$

Introduction

School outcomes and good performance in different subjects depends on children's ability to read. Therefore, teaching children how to read during early grades is critical (Mwoma, 2017). Children who do not learn to read well are more likely to be retained in a grade in school and are likely to drop out when they reach high school (Connor, Alberto, Compton \& O'Connor, 2014). Without strong reading literacy development, learners have to battle to be successful in their educational progression throughout schooling which has dire consequences for their future prospects. Therefore, reading literacy needs to be a central school activity (Zimmerman, 2018). This study investigated factors affecting reading literacy looking at the relationship between instructional materials and pupils' English reading literacy. English reading literacy comes from the words namely; reading and literacy. Defined, reading is an interactive process between readers and texts that result in reading fluency (Gilakjani \& Sabouri, 2016).

On the other hand, literacy is the process of using reading, writing, and oral language to extract, construct, integrate, and critique meaning through interaction and involvement with multimodal texts in the context of socially situated practices (Frankel, Becker, Rowe \& Pearson, 2016). The concept of English reading literacy in this text explained ability to spell and pronounce words and accuracy of reading (Kunert \& Scheepers, 2014). For instructional materials, these refer to all the tools which are needed by the teacher to provide help and encouragement to pupils' learning activities. In the words, instructional materials are resources or teaching materials which a teacher utilises in the course of presenting a lesson in order to make the content of the lesson understandable to the learners (Chukwu, Eze \& Agada, 2016). Instructional materials in this study were described as conceptualised by Yusta et al. (2016) as referring to audio-visual resources, graphic resources and realia resources. Audio-visual resources covered videos, audio messages, textbooks and chalkboard. Graphic resources included word cards, charts and English kits. Realia resources refer to resources such as physical objects and humans among others that can enhance pupils' English reading literacy in primary schools.

\section{Background}

The concern about reading literacy is not new and has been a concern of educators for a long time. For instance, Frame (1964) reported that in the USA at the time there was concern that the amount of reading done in the country was small. In 2003 the United Nations Convention in Prague stipulated that basic literacy skills were the key for a literate community in the face of the rapid flow of information technology. The five essential components of 
information literacy identified were basic literacy, library literacy, media literacy, technology literacy, and visual literacy (Erwinsah, Solin \& Adisaputera, 2019). The United States Agency for International Development (USAID) has been using Early Grade Reading Assessment tests to measure how children acquire reading skills in early grades of primary schools in different countries in the world. The results of these tests help tell whether pupils are progressing well in achieving reading fluency and comprehension, that is critical in children's learning to read, as they transit to reading to learn (Mwoma, 2017). Western World countries give prominence to reading literacy of pupils. For instance, since 1969, the USA government regularly measures the reading skills of schoolage population with the National Assessment of Educational Progress (NAEP) tracking the reading performance of learners periodically. The assessment measures reading comprehension by asking students to read selected grade-appropriate materials (NAEP, 2019).

In African countries reports reveal that reading literacy is a still a big challenge. For instance, it has been reported that in South Africa learners have reading problems, regardless of which language they read in (Zimmerman, 2018). In Ethiopia, an early grade reading assessment carried out in May and June 2010 by the Ministry of Education (MOE), RTI International, members of the Education and Training Quality Assurance Agency (ETQAA), and the Improving Quality in Primary Education Program (IQPEP) in a collaboration revealed that pupils reading capacity was below the expected level (Teshome, 2014). In Kenya, Mwoma (2017) in a study on children's reading ability in early primary schooling revealed that for both boys and girls reading literacy was far below average in the reading of tasks in both English and Kiswahili which are the official national languages. Accordingly, this pointed to the fact that children were not well prepared in the pre-reading skills acquired in preschool and the reading skills acquired in the early grades one and two.

In Uganda, the introduction of reading literacy can be traced to the establishment of church mission schools towards the end of the $19^{\text {th }}$ century. During the time, emphasis was on imparting reading, writing and rhetoric skills (Kisitu \& Ssebunya, 2016). Education emphasised reading and writing very much and the consequence in most of the Ugandan languages, going to school is called going to read books which means one is going to school to read or one is in school to read (Ssekamwa, 1997). The course of instruction varied considerably in different parts of the country. In the schools in the remoter districts, reading, writing, and arithmetic were stressed but at such centres as Kampala, Hoima, Kabale and Fort Portal in Kabarole, English was taught, and such subjects as dictation, geography, and grammar were also part of the curriculum. Bible reading and religious teaching formed the basis of all the instruction (Khadidja, 2014). Reading literacy of the pupils in schools was very high with pupils' reading and speaking fluently. However, the trend changed in the 1970s as the period was characterised by the turbulence of the regime at the time which affected all sectors of life including teacher's welfare. This situation has continued up today (Mazaki, 2017).

To address the situation and improve pupils reading, the government of Uganda has made two interventions, namely the School Health and Reading Program (SHRP; 2012-2019) and the Literacy Achievement and Retention Activity (LARA; 2015-2020). The two early-learning programs are implemented by Research Triangle Institute (RTI). The programs focus on early grade reading, support $80 \%$ of public primary schools, reaching 6 million pupils in 9,750 schools. Through ministry systems, the programs support development of reading materials; methods and training for teaching reading; development of a literacy framework; and incorporation of reading methods into the pre-service teacher training curriculum (Gove et al., 2017). Also, different stakeholders in the education sector in Uganda have put in place mechanisms to promote reading literacy. For instance, the government of Uganda has been giving grants to all government aided primary schools to cover instructional materials (Republic of Uganda, 2008). Teachers have also been equipped with skills to use local material to make charts which decorate classrooms for the pupils to read. Local materials like banana fibres, ropes and sculptures are being used as visual aids in the classes (Kijambu, 2009). However, according to Mukasa and Masembe (2018), literacy level in English has been noted to be very low among school children with only $25 \%$ of the pupils enrolled in grade three possessing the required literacy skills, and the trend of learner achievement almost has remained constant since 2015. Many of the children complete the primary school cycle without acquiring basic literacy skills.

The UWEZO Report (2016) revealed that nationally, 3 out of 10 pupils in P3-P7 could read an English story. In P3, 2 out of 10 could read and understand an English story. Accordingly, the children enrolled in primary schools are developing the intended reading skills relatively late. It is only by P5 that about half of the children in the country can read and understand a short P2 level story in English. Therefore, it is only at P5 and above that a majority of pupils are fully successful at the P2 level reading. Even at P7, the final year of the primary education cycle, at least 2 out of 10 children are able to complete reading tasks at P2 level. This implies that a substantial number of children continue to complete primary education without ever having acquired the basic literacy competencies critical to further learning and independent and social living. The continued low reading literacy despite the different interventions to provide instructional materials attracted this study to investigate whether instructional materials determined English reading literacy of pupils. 


\section{Literature Review}

Theoretical Review

This study was underpinned by the Experiential Learning Theory (ELT) advanced by Kolb in 1984. ELT defines learning as the process whereby knowledge is created through the transformation of experience. ELT posits that for effective learning to transpire, the learner must go through the entire cycle (Passarelli \& Kolb, 2011). The four stage learning model depicts two polar opposite dimensions of grasping experience - concrete experience (CE) and abstract conceptualization (AC), and two polar opposite dimensions of transforming experience - reflective observation (RO) and active experimentation (AE). Experiential learning is a process of constructing knowledge that involves a creative tension among the four learning abilities (Kolb \& Kolb, 2009). The four stages presuppose that learning must go through each stage - experiencing, reflecting, thinking, and acting. In the grasping experience the learner can perceive new information through experiencing the concrete, tangible, felt qualities of the world such as instructional materials. The learner is thus able to rely on his/ her senses and get immersed in concrete reality hence able to learn (McCarthy, 2016). From ELT, it emerged that when a learner experiences, reflects, thinks and acts on instructional materials, then the learner might learn effectively. ELT was thus the basis for relating instructional materials and pupils English reading literacy.

\section{Audio-Visual Instructional Materials and English Reading Literacy}

Audio-visual instructional materials can be classified into three categories that are audio, video and visual. Audio instructional materials refer to such materials as tape recording cassettes, radio, CD and dramatisation. Video instructional resources are such resources such as television, video recording, motion pictures with soundtracks, slides, videos and multimedia, computer and DVD. Visual resources include such resources as pictures, diagram buildings, projectors, teacher themselves, charts, real objects, books, newspapers, magazines, pamphlets, handouts, clock face, simple abacus, coloured objects, puppets, models and chalkboard (Yusta et al., 2016). There are scholars that have studied the relationship between audio-visual instructional materials and English reading literacy. For instance, Al-Khayyat (2016) reported that using audio-visual aids (AVA), and computerised materials had a positive effect on the experimental group students' achievement. Nalliveettil and Odeh (2013) revealed that using audio-visuals as a teaching method stimulated thinking and improved learning environment in a classroom. Accordingly, effective use of audio-visual aids substituted monotonous learning environments. Students developed and increased personal understanding of the areas of learning when they experienced a successful and pleasant learning in the EFL classroom.

Ode (2014) revealed that the use of audio-visual resources had significant impact on the teaching and learning in secondary schools. Omuna et al. (2016) found out that textbooks were the most used instructional resources and instructional resources positively correlated with the learning of English reading skills. Salazar and Larenas (2018) reported that there was a positive change in students' performance and that learners regarded the strategy as beneficial, which supported the belief that the inclusion of audio-visual aids benefitted young learners when learning English. Shabiralyani, Hasan, Hamad and Iqbal (2015) indicated that the majority of the teachers and students had positive perceptions of the use of visual aids. Sowntharya, Gomathi and Muhuntarajan (2014) established that the media played an effective role both in language teaching and language learning. The literature above suggested that significant effort had been expended by scholars to analyse the relationship between audiovisual instructional materials and pupils English reading literacy. However, contextual gaps emerged with all the studies conducted in the context outside Uganda. This contextual gap made it imperative for this study in the context of Uganda to be carried to assess whether audio-visual instructional materials contributed to the variation in pupils English reading literacy in primary schools.

\section{Graphic Instructional Materials and Pupils English Reading Literacy}

Graphics instructional materials refer to resources such as teaching charts, picture board, letter or word cards, tracing paper, puzzles, matching cards, picture book, reading board, cartoon books and stacking toys among (Yusta et al., 2016). Effective use of graphical illustration in designing instructional material has been suggested as an important facet of instructional message design. Using illustrations in instructional material is an effective method to support learning because it can be used as interest-creating device and it also helps the learner to interpret and remember the context of illustrated text (Park, Kim, Lee \& Lee, 2005). There are a number of studies that have been carried out on the relationship between graphic instructional materials and pupils English reading literacy. However, Ajoke (2017) in his study revealed that there were no significant differences in the performance of students taught using of visual instructional materials including graphic materials and those taught without the use of instructional materials. Nevertheless, Akanmu and Fajemidagba (2017) reported that students taught with the aid of graphical materials had significantly higher mean gain scores.

In relation to the above, Baglama et al. (2017) indicated that effectiveness of using graphics in education and the facilitative role of graphics enhanced learning of individuals with learning difficulties. On the contrary, 
Park et al. (2005) revealed that there were no significant differences between learner's motivations among three illustration groups. Praveen and Premalatha (2013) found out that the experimental group of students improved in all of reading questions compared to control group of students. Uba, Oteikwu, Onwuka and Abiodun-Eniayekan (2017) identified that graphic instructional materials made students take charge of the learning process in prose literature classes, and guaranteed student understanding and achievement. On the whole, the literature above showed that scholars had made an attempt to relate graphic instructional materials and reading literacy. However, empirical gaps emerged with some studies producing controversial results. For instance, while all the other studies revealed that graphic instructional materials determined the differences in English reading literacy, the study by Ajoke (2017) and Park et al. (2005) revealed no significant difference in the performance of students taught using graphical instructional materials. These empirical gaps made it imperative for this study in the context of primary schools in Uganda to further examine whether graphic instructional materials determined the variation pupils.

\section{Realia Instructional Materials and Pupils English Reading Literacy}

Realia resources are real objects like posters, flags, magazines, plants, water, pictures, graphics, animals, coins and seeds. Instructional resources play a significant role in the teaching and learning process. Some students may not understand complex concepts. Similarly, they may not remember to build on the existing knowledge to help them master what they do not know yet. Adequacy of instructional resources enables learners to follow the teacher's sequence of the lesson presentation and subsequently aid in the understanding of the lesson (Yusta, Karugu, Muthee \& Tekle, 2016). Realia provides first-hand or direct experiences to the learners. Real specimens such as plants, machines or tools enrich learning and make it more concrete, authentic and interesting as the learner is made to handle and study these things directly (Utibe-Abasi, 2016). Argawati (2009) reported that when teachers taught using realia materials, students recognised the things and remembered the names easily, their interest to the lessons increased and boredom during the lesson died out. Bably and Nusrat (2017) found out that using realia stimulated the mind, and encouraged creativity by involving the senses in the learning process.

Hadi (2018) indicated that appropriate use of realia in English lesson classrooms served to create an active teaching environment and helped to create a link between the objects and the words or phrases they represent. Further, the study showed that use of real objects encouraged students to learn texts with interest, and understand the abstract ideas in the text. Olatoye (2017) reported that in order to have good understanding and retention of what is being taught in class by teachers, an effective use of instructional aids especially realia is required. Realia materials make learning process easier, which is why teachers should use them for better teaching. Utibe-Abasi (2016) found out that realia materials had significant effects on students' academic performance. Yusta et al. (2016) revealed that realia resources were most commonly used by teachers and had a significant positive influence on learning. Generally, the literature above showed that scholars had carried out a number of studies on realia instructional materials and pupils English reading literacy. Nonetheless, the literature suggested that none of the studies was carried out in schools in Uganda whose classroom contexts might have been different. These contextual gaps made it imperative for this study in the context of schools Uganda to seek to evaluate whether realia instructional materials determined the variation pupils reading literacy in primary schools.

\section{Methods \\ Sample and Procedure}

The sample size was 411 primary pupils of Buhinga, Kitumba and Kahinju primary schools in Fort portal Municipality in Western Uganda. The sample comprised 203 (in streams A and C) as an experiment group and 208 (in streams B and D) as the control group. While the pupils in Kitumba Primary comprised one stream, the pupils were systematically divided into streams A and B for purposes of the study. The study adopted the experimental research design to establish if an intervention into the study groups measured the outcomes of the treatment. The intervention in this study was the use of instructional materials. Since the study involved minors, to maintain research ethics, after the Institutional Research and Ethics Committee of Kampala International University had approved to study to be carried out, informed assent for minors (8-12 years) was obtained from the head teachers allowing the study to be conducted in the schools.

\section{Data Collection Instrument}

The data collection instrument was an English reading test that was administered to the pupils. The test was divided into three sections, namely; audio-visual, graphic and realia resources respectively. The first section on audiovisual comprised four subsections with each subsection comprising three questions all carrying three marks. The second subsection on graphic had three subsections with each subsection comprising three questions all carrying three marks. Section three on realia resources was made up of one question with three questions all carrying three marks. To attain the validity and reliability of the test, the English reading test was subjected to modulation by two senior teachers of English. The teachers after suggesting some corrections confirmed that the test was a standard one for a primary four class. This ensured the validity and reliability of the test. 
Data Analysis

After data collection, the data were coded entered the data into the computer using the Statistical Package for Social Sciences (SPSS 24.0), summarised using frequency tables to identity errors and edited to remove errors. Data analysis involved inferential analysis that is Student's t Test by which comparisons between the dependent variable (DV) English reading literacy and the pupils' categorisation (experiment and control groups) were tested. SPSS facilitated the data analysis.

\section{Results}

Audio-Visual Instructional Materials and Pupils' English Reading Literacy. This section analysed data on whether audio-visual instructional materials contributed to the variation in pupils' English reading. One group of pupils was taught using video, audio, textbook and chalk board teaching materials and another was not. The results on the same were as presented in Table 4.1.

Table 1: Student's t Test Results on Audio-Visual Instructional Materials and Pupils' English Reading

\begin{tabular}{lccccc}
\multicolumn{1}{c}{ Literacy } & $\mathrm{N}$ & Mean & Std. Deviation & $\mathrm{t}$ & $\mathrm{p}$ \\
\hline Test Group & 164 & 2.32 & 0.38 & 7.849 & 0.000 \\
\hline Experimental Group & 163 & 1.96 & 0.46 & & \\
Control Group & & & &
\end{tabular}

The results in Table 1 showed that on average, experimental groups (mean $=2.32)$ scored higher in English reading literacy than those of the control group (mean $=1.96)$. The Students $t(t=7.849)$ was large and the $p$-value $(p=$ $0.000)$ below $0.05(\mathrm{p}<0.05)$. The results suggested that English reading literacy differed significantly among pupils taught using audio-visual and those not. Therefore, teaching audio-visual instructional materials contributed to the variation in pupils' English reading literacy.

Graphic Instructional Materials and Pupils' English Reading Literacy. This section analysed data on whether graphic instructional materials contributed to the variation in pupils' English reading. One group of pupils was taught using word cards, charts and English kits and another was not. The results on the same were as presented in Table 2 .

Table 2: Student's t Test Results on Graphic Instructional Materials and Pupils' English Reading Literacy

\begin{tabular}{lccccc}
\hline Test Group & $\mathrm{N}$ & Mean & Std. Deviation & $\mathrm{t}$ & $\mathrm{P}$ \\
\hline Experimental Group & 164 & 2.23 & 0.47 & 8.237 & 0.000 \\
Control Group & 163 & 1.80 & 0.45 & & \\
\hline
\end{tabular}

The results in Table 2 indicate that on average, experimental groups (mean $=2.23)$ scored higher in English reading literacy than those of the control group (mean $=1.80)$. The Students $t(t=8.237)$ was large and the $p$-value $(p=$ $0.000)$ below $0.05(\mathrm{p}<0.05)$. The results meant that English reading literacy differed significantly among pupils taught using graphical instructional materials and those not. Therefore, teaching using graphic instructional materials determined the variation in pupils reading literacy.

Realia Instructional Materials and Pupils' English Reading Literacy. This section analysed data on whether realia instructional materials contributed to the variation in pupils' English reading. One group of pupils was taught using physical objects and humans and another was not. The results on the same were as presented in Table 3.

Table 3: Student's t Test Results on Realia Instructional Materials and Pupils' English Reading Literacy

\begin{tabular}{lccccc}
\hline Test Group & $\mathrm{N}$ & Mean & Std. Deviation & $\mathrm{t}$ & $\mathrm{P}$ \\
\hline Experimental Group & 164 & 2.46 & 0.59 & 10.518 & 0.000 \\
Control Group & 163 & 1.81 & 0.51 & & \\
\hline
\end{tabular}

The results in Table 3 reveals that on average, experimental groups (mean $=2.46)$ scored higher in English reading literacy than those of the control group (mean $=1.81)$. The Students $\mathrm{t}(\mathrm{t}=10.518)$ was large and $\mathrm{p}$-value $(\mathrm{p}=$ $0.000)$ was below $0.05(\mathrm{p}<0.05)$. The results indicate that English reading literacy differed significantly among pupils taught using realia instructional materials and those not. Therefore, teaching realia instructional materials determined the variation pupils reading literacy. 


\section{Discussion}

The finding that audio-visual instructional materials contribute to the variation in pupils' English reading literacy was consistent with the findings of of previous scholars. For example, Al-Khayyat (2016) reported that using audio-visual aids and computerised materials had a positive effect on the experimental group students' achievement. Nalliveettil and Odeh (2013) revealed that effective use of audio-visual aids substituted monotonous learning environments making learners have increased personal understanding. Also, Ode (2014) found out that use of audio-visual resources had significant impact on the teaching and learning in secondary schools. Omuna et al. (2016) established that that textbooks one of the audio-visual instructional materials were the most used instructional resources and instructional resources positively correlated with the learning of English reading skills. Salazar and Larenas (2018) reported that inclusion of audio-visual aids benefitted young learners when learning English. Shabiralyani et al. (2015) established that majority of the teachers and students had positive perceptions of the use of visual aids. Sowntharya et al. (2014) in their study revealed that audio visual media played an effective role both in language teaching and language learning. With the finding of the study being consistent with the findings of all previous scholars, it can be deduced that audio-visual instructional materials contributed to the variation in pupils' English reading literacy in primary schools.

With respect to the finding that graphical instructional materials contributed to the variation in pupils' English reading literacy in primary schools, it agreed with the findings of most previous scholars. For instance, Akanmu and Fajemidagba (2017) revealed that students taught with the aid of graphical materials had significantly higher mean gain scores. Baglama et al. (2017) reported that effective use of graphics enhanced learning of individuals with learning difficulties. Praveen and Premalatha (2013) established that using graphic instructional materials was effective in teaching reading and helped pupils to identify the main idea. Uba et al. (2017) revealed that graphic instructional materials made students take charge of the learning process in prose literature classes, and guarantee student understanding and achievement. However, the finding was contrary to the finding by Ajoke (2017) who revealed no significant differences in the performance of students taught with graphic materials and those taught without the use of instructional materials. Also, Park et al. (2005) reported that there were no significant differences in motivations of learners taught using illustrations and others. However, while Ajoke (2017) and Park et al. (2005) indicated that graphic materials had no positive significant influence on performance students, still it was inferred that graphic materials had a positive significant influence on performance students because the finding of the study agreed with the findings of the larger number of scholars.

Lastly, the finding to the effect that realia instructional materials contributed to the variation in pupils' English reading literacy concurred with the findings of scholars such as Argawati (2009) who found out that when teachers used realia educational tools in teaching English vocabulary, students recognised the things and remembered the names easily, their interest to the lessons increased and boredom during the lesson died out. Bably and Nusrat (2017) established that using realia stimulated the mind, and it encouraged creativity by involving the senses in the learning process. Hadi (2018) reported that proper use of realia was an efficient visual aid that helped teachers to achieve efficient learning. Olatoye (2017) indicated that real materials made learning process easier. Utibe-Abasi (2016) established that realia had significant effects on students' academic performance as students taught using realia showed superiority in performance over the control group. Yusta et al. (2016) revealed that realia resources had a significant positive influence on learning. With findings of the study concurring with the findings of all previous scholars, it was confirmed that realia instructional materials contributed to the variation in pupils' English reading literacy in primary schools.

\section{Conclusions}

The discussion above led to the drawing of the following conclusions on the use of instructional materials in the teaching of English reading literacy. First, audio-visual instructional materials are important for pupils' English reading literacy in primary schools. This is especially when teachers use audio-visual instructional materials that include videos, audio messages, textbooks and chalkboard. Also, the use of graphic instructional materials is essential for pupils reading literacy in primary schools. Such graphic instructional materials graphic resources will involve word cards, charts and English kits. Further still, the use of realia instructional materials are imperative for pupils reading literacy in Primary Schools. The realia instructional materials include materials such as physical objects and humans among others. Therefore, it is recommended that the Ministry of Education, head teachers and proprietors of schools should help teachers in primary schools to emphasise the use of audio-visual instructional materials in teaching of English reading literacy. Teachers should be provided instructional materials such as videos, audio messages, textbooks and chalkboard. Also, teachers in primary schools should emphasise the use of graphic instructional materials in teaching of reading literacy in primary schools. Such graphic instructional materials should include word cards, charts and English kits. Furthermore, teachers in primary schools should prioritise the use of realia instructional materials in teaching of English reading literacy to pupils in primary schools. The realia instructional materials should include materials such as physical objects and humans among others. 
References

Ajoke, A. R. (2017). The importance of instructional materials in teaching English as a second language. International Journal of Humanities and Social Science Invention, 6(9), 36-44.

Akanmu, M. A., \& Fajemidagba, M. O. (2017). The use of graphical materials teaching of mathematics: Effects of students' understanding and performance. Available at: https://journal.phnoe.ac.at/index.php/resource/article/view/153

Al-Khayyat, A. S. J. (2016). The impact of audio-visual aids (AVA) and computerize materials (CM) on University ESP students' progress in English Language. International Journal of Education and Research, 4(1), 273282.

Argawati, N. O. (2009). The effectiveness of using realia in teaching english vocabulary to the $3^{\text {rd }}$ grade of elementary school student in SD Bentakan I Baki Sukoharjo (Masters Dissertation, Sebelas Maret University Surakarta, Indonesia)>

Bably, T., \& Nusrat, D.(2017). Using realia as an effective pedagogical tool. IOSR Journal of Humanities and Social Science (IOSR-JHSS), 22(11), 01-07.

Baglama, B., Yucesoy, Y., Uzunboylu, H., \& Özcan, D. (2017). Can infographics facilitate the learning of individuals with mathematical learning difficulties? International Journal of Cognitive Research in Science, Engineering and Education/IJCRSEE, 5(2), 119-12.

Bendriss, R., \& Golkowska, K. (2011). Early reading habits and their impact on the reading literacy of Qatari undergraduate students. Arab World English Journal, 2(4), 38-57.

Brooks, J., McCluskey, S., Turley, E., \& King, N. (2015). The utility of template analysis in qualitative psychology research. Qualitative Research in Psychology, 12(2), 202-222.

Camm, A. J., \& Fox, K. A. (2018). Strengths and weaknesses of 'real-world' studies involving non-vitamin K antagonist oral anticoagulants. Open heart, 5(1), 1-12.

Connor, C. M., Alberto, P. A., Compton, D. L., O’Connor, R. E. (2014). Improving reading outcomes for students with or at risk for reading disabilities: A synthesis of the contributions from the institute of education sciences research centers. Washington, DC: National Center for Special Education Research, Institute of Education Sciences.

Douglas, J., \& Lawton, K. (2016). A strategy to get England's children reading. London, UK: Save the Children.

Ellis, T. J., \& Levy, Y. (2009). Towards a Guide for Novice Researchers on Research Methodology: Review and Proposed Methods. Issues in Informing Science \& Information Technology, 6, 323-237.

Erwinsah, E., Solin, M., \& Adisaputera, A. (2019). The concept of school literacy movement through reading time at SDIT Raudaturrahmah Pekanbaru. Budapest International Research and Critics in Linguistics and Education (BirLE) Journal, 2(1), 145-157.

Erwinsah, E., Solin, M., \& Adisaputera, A. (2019). The Concept of School Literacy Movement Through Reading Time at SDIT Raudaturrahmah Pekanbaru. Budapest International Research and Critics in Linguistics and Education (BirLE) Journal, 2(1), 145-157.

Frame, N. (1964). The availability of reading material)ls for teachers and pupils at the primary level. Elementary English, 41(3), 224-229.

Frankel, K. K., Becker, B. L., Rowe, M. W., \& Pearson, P. D. (2016). From "what is reading?" to what is literacy? Journal of Education, 196(3), 7-17.

Gale, N.K., Heath, G., Cameron, E., Rashid, S., \& Redwood, S., 2013. Using the framework method for the analysis of qualitative data in multi-disciplinary health research. BMC Medical Research Methodology, 13(117). Available at: https://doi.org/10.1186/1471-2288-13-117.

Gilakjani, A. P., \& Sabouri, N. B. (2016). How can students improve their reading comprehension skill? Journal of Studies in Education, 6(2), 229-240.

Gove, A., Brunette, T., Bulat, J., Carrol, B., Henny, C., Macon, W., Nderu, E., \& Sitabkhan, Y. (2017). Assessing the impact of early learning programs in Africa. In Kenneth R. Pugh, Peggy McCardle, \& Annie Stutzman (Eds.), Global approaches to early learning research and practice: New directions for child and adolescent development. 158, 25-41

Gravlee, C. C., Kennedy, D. P., Godoy, R., \& Leonard, W. R. (2009). Methods for collecting panel data: What can cultural anthropology learn from other disciplines? Journal of Anthropological Research, 65(3), 453483.

Greasley, P. (2007). Quantitative data analysis using SPSS: An introduction for health and social science. New York, USA: McGraw-Hill Education.

Guetterman, T. C., Fetters, M. D., \& Creswell, J. W. (2015). Integrating quantitative and qualitative results in health science mixed methods research through joint displays. The Annals of Family Medicine, 13(6), 554-561.

Hadi, A. S. A. (2018). Effectiveness of using realia in teaching English vocabulary for ESL learners'. International Journal of Engineering Science Invention (IJESI), 7(10), 65-72. 
Harrell, M.C., \& Bradley, M.A. (2009). Data collection methods: Semi-structured interviews and focus groups. Santa Monica, USA: RAND National Defence Research Institute.

Jamshed, S. (2014). Qualitative research method-interviewing and observation. Journal of Basic and Clinical Pharmacy, 5(4), 87-88.

Kajubu, E. (2009, May 20). Kabarole teachers develop own materials for teaching thematic curriculum. URN. Available at:

Kewaza, S., \& Welch, M. I. (2013). Big Class Size Challenges: Teaching Reading in Primary Classes in Kampala, Uganda's Central Municipality. Online Submission, 3(5), 283-296.

Khadidja, D. (2014). Western Education in Uganda (Masters Dissertation, University of Oran, Algeria).

Kisitu, G., \& Ssebunya, M. (2016). Examining the contribution of the colonial education system vis-à-vis leadership and service delivery in Uganda. International Journal of Humanities and Social Science, 6(11), 259-269

Kolb, A. Y., \& Kolb, D. A. (2009). Experiential learning theory: A dynamic, holistic approach to management learning, education and development. The SAGE handbook of management learning, education and development, 42-68.

Kunert, R., \& Scheepers, C. (2014). Speed and accuracy of dyslexicversus typical word recognition: An eyemovement investigation. FrontiersinPsychology, 5(2), 1-16.

Lan, D. T. H., Huyen, P. M., \& Huong, L. T. T. (2017). The effectiveness of the experiential learning activities in developing English speaking skills for students at Thai Nguyen University of Economics and Business Administration - TNU. IOSR Journal of Research \& Method in Education (IOSR-JRME), 7(4), 83-87. 10.9790/7388-0705048387

Leahy, M. A., \& Fitzpatrick, N. M. (2017). Early readers and academic success. Journal of Educational and Developmental Psychology, 7(2), 87-95.

Martínez-Mesa, J., González-Chica, D. A., Duquia, R. P., Bonamigo, R. R., \& Bastos, J. L. (2016). Sampling: how to select participants in my research study? Anais brasileiros de dermatologia, 91(3), 326-330.

Mazaki, K. E. (2017). Staff welfare and teachers'performance in public primary schools in Bugisu Sub-Region in Uganda (PhD proposal, Mbarara University of Science And Technology, Mbarara Uganda).

McCarthy, M. (2016). Experiential learning theory: From theory to practice. Journal of Business \& Economics Research (Online), 14(3), 131-140.

Mellahi, K., \& Harris, L. C. (2016). Response rates in business and management research: An overview of current practice and suggestions for future direction. British Journal of Management, 27(2), 426-437.

Mollaei, F., \& Rahnama, H. (2012). Experiential education contributing to language learning. International Journal of Humanities and Social Science, 2(21), 268-279.

Mukasa, J. K., \& Masembe, E. (2018). Practices of teaching reading in Ugandan Primary Schools: The case of Luganda local language. International Journal of Education and Research, 6(4), 127-138.

Mwoma, T. (2017). Children's reading ability in early primary schooling: Challenges for a Kenyan rural community. Issues in Educational Research, 27(2), 347-3664.

NAEP. (2019). NAEP reading - Reading Assessment. Available at: https://nces.ed.gov/nations report card/reading/

Nalliveettil, G. M., \& Odeh, A. H. A. (2013). Study on the usefulness of audio-visual aids in efl classroom: Implications for effective instruction. International Journal of Higher Education, 2(2), 86-92.

Ngaka, W., \& Masaazi, F. M. (2015). Participatory Literacy Learning in an African Context: Perspectives from the Ombaderuku Primary School in the Arua District, Uganda. Journal of Language and literacy Education, 11(1), 88-108.

Ochwo, J. (2019). Report on schools in Fort Portal Municipality. Fort Portal, Uganda: Buhinga Coordinating Centre.

Ode, E. O. (2014). Impact of audio-visual (AVs) resources on teaching and learning in some selected private secondary schools in Makurdi. International Journal of Research in Humanities, Arts and Literature (IMPACT: IJRHAL), 2(5), 195-202.

Olatoye, R. A. (2017). Effect of teaching using charts, real specimens and videos on secondary school students' achievement in Mammalian Skeletal System Concepts .Revista de la Facultad de Educación de Albacete, 32(2), 63-75.

Omuna, M. O., Onchera, P. O., \& Kimutai, C. K. (2016). Availability and use of instructional resources for teaching and learning of English reading skills in secondary schools in Teso North Sub County, Kenya. Educational Research, 7(1), 001 -009,

Park, S., Kim, M., Lee, Y., Son, C., \& Lee, M. (2005). The effects of visual illustrations on learners' achievement and interest in PDA-(Personal Digital Assistant) based learning. Journal of Educational Computing Research, 33(2), 173-187. 
Passarelli, A. M., \& Kolb, D. A. (2011). The learning way-Learning from experience as the path to lifelong learning and development. In The Oxford handbook of lifelong learning (pp. 70-90). M London Editor Oxford University Press.

Praveen, S. D., \& Premalatha, R. (2013). Using graphic organizers to improve reading comprehension skills for the Middle School ESL students. English Language Teaching, 6(2), 155-170.

Pretorius, E. J., \& Klapwijk, N. M. (2016). Reading comprehension in South African schools: Are teachers getting it, and getting it right? Per Linguam: a Journal of Language Learning= Per Linguam: Tydskrif vir Taalaanleer, 32(1), 1-20.

Rashid, S., \& Brooks, G. (2010). The levels of attainment in literacy and numeracy of 13- to 19-year-olds in England, 1948-2009 research report. London, UK: NRDC Institute of Education.

Republic of Uganda. (2008). The Education (Pre-Primary, Primary And Post-Primary) Act, 2008. Entebbe, Uganda: UPPC, Entebbe.

Saban, A. (2002). The theory of intelligence and education. Ankara, Turkey: Nobel Yayin Dagitim.

Salazar, G. U., \& Larenas, C. D. (2018). Using an audiovisual materials-based teaching strategy to improve EFL young learners' understanding of instructions. $H O W, 25(2), 1-112$.

Shabiralyani, G., Hasan, K. S., Hamad, N., \& Iqbal, N. H. (2015). Impact of visual aids in enhancing the learning process case research: District Dera Ghazi Khan. Journal of Education and Practice, 6(19), 226-33.

Sowntharya, D. Y., Gomathi, S., \& Muhuntarajan, C. (2014). Audio visual media and English learners. International Journal on Recent and Innovation Trends in Computing and Communication, 2(2), 384 386.

Spichtig, A. N., Hiebert, E. H., Vorstius, C., Pascoe, J. P., Pearson, P. D., \& Radach, R. (2016). The decline of comprehension-based silent reading efficiency in the United States: A comparison of current data with performance in 1960. Reading Research Quarterly, 51(2), 239-259.

Ssekamwa, J. C. (1997). History and Development of Education in Uganda. Kampala, Uganda: Fountain Publishers Ltd.

Teshome, G. (2014). Teaching reading skills in second cycle (5-8) of primary school in Oromiya Region: Focus to East Wollega and IlluAbabor Zones. International Journal of Sciences: Basic and Applied Research (IJSBAR), 17(1), 95-109.

Uba, E., Oteikwu, E. A., Onwuka, E., \& Abiodun-Eniayekan, E. (2017). A research-based evidence of the effect of graphic organizers on the understanding of prose fiction in ESL classroom. SAGE Open, 7(2), 1-9.

Utibe-Abasi, S. S. (2016). Effects of realia and models instructional materials on academic performance in physics among senior secondary school students in Akwa Ibom State. Nigeria. International Journal of Educational Benchmark (IJEB), 3(1), 45-53.

Uwezo. (2016). Are Our Children Learning? Uwezo Uganda $6^{\text {th }}$ Learning Assessment Report. Kampala: Twaweza East Africa.

Williams, C. (2011). Research methods. Journal of Business \& Economic Research, 5(3), 65-72.

Yusta, N., Karugu, G., Muthee, J., \& Tekle, T. (2016). Impact of instructional resources on mathematics performance of learners with dyscalculia in integrated primary schools, Arusha City, Tanzania. Journal of Education and Practice, 7(3), 12-18.

Zimmerman, L. (2018). Learning from the best: reading literacy development practices at a high-performing primary school. Per Linguam: A Journal of Language Learning= Per Linguam: Tydskrif vir Taalaanleer, 33(2), 36-50. 